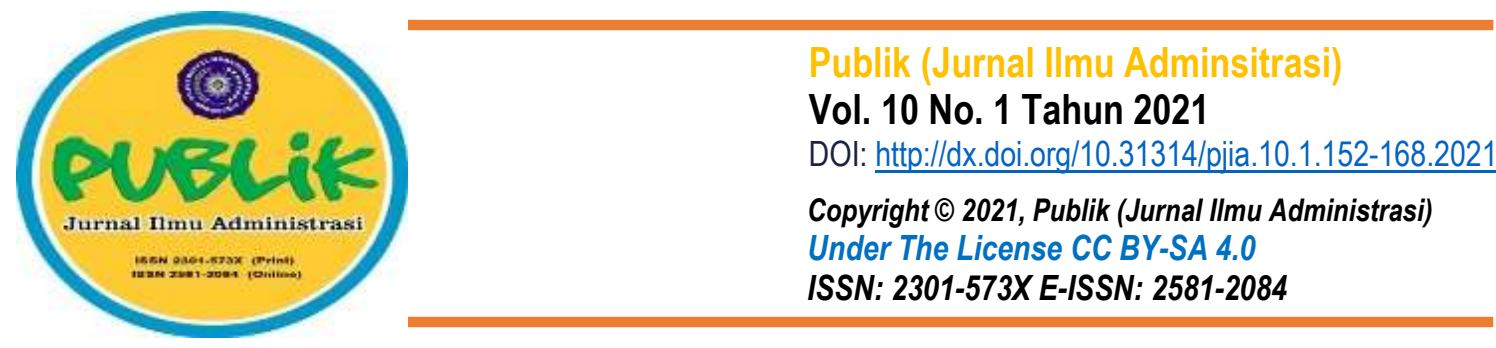

\title{
Critical Analysis of Indonesia's Global Maritime Fulcrum under Joko Widodo: Problems and Challenges
}

Alfiyan Nooryan Putra Pikoli

Program Pascasarjana Hubungan Internasional, Universitas Indonesia

Email: alvean6@gmail.com

Abstract The vision of the Global Maritime Fulcrum (GMF) for Indonesia not only raises national awareness but also gets international attention. Jokowi in the first term of his administration echoed this vision as the identity of his foreign policy. However, in its implementation, there are various shortcomings. As a result, the vision did not work out well. Especially during his second election as president of Indonesia, Jokowi no longer mentioned GMF as a priority policy. This paper aims to analyze the causes of the failure to implement the GMF vision in Jokowi's first term as president. Several previous studies on GMF were divided into 3 major studies, namely security studies, international cooperation, then regional and geopolitical studies. Most of these studies discuss GMF Indonesia's vision only in the international scope, such as cooperation formed with other countries, its influence on the region, geopolitical implications, and on the perspective of threats and security. There is no research that specifically addresses the problems and challenges of the GMF. By the governmental and leadership approach in policy studies, this paper identifies the factors that have resulted in the GMF vision's lack of implementation. This article argues that uncoordinated governance, overlapping institutions, and Jokowi's lack of leadership are the main determinants of the success or failure of the GMF vision. The limitations of this study allow for further analysis of the economic perspective of GMF in subsequent studies.

Keywords: Maritime Fulcrum; Policy Studies; Leadership; Governmental

Received:23-02-2021 Revised:06-05-2021 Accepted:07-06-2021

\section{INTRODUCTION}

President Joko Widodo's (Jokowi) maritime vision of Indonesia as a Global Maritime Fulcrum (GMF) attracted international attention during the early days of his reign. This idea was first introduced by Jokowi internationally at the 9th East Asia Summit in Nay Pyi Taw, Myanmar, on November 13, 2014 (Indonesia.go.id, 2019). Jokowi is optimistic that this idea will strengthen Indonesia's strategic position, with nearly $40 \%$ of international trade passing through its sea area. Even to realize the idea of GMF, Jokowi has prepared it in the form of a national policy based on five main pillars. First, rebuild the maritime culture. Second, maintaining and managing marine resources with a focus on building seafood sovereignty through the development of the fishing industry by placing fishers as the central pillar. Third, maritime infrastructure and connectivity are 
developed by building sea highways, deep seaports, logistics, shipping industry, and marine tourism. Fourth, develop maritime diplomacy by jointly eliminating sources of conflict at sea. Lastly, build a maritime defence force. These five pillars will support the formation of the idea of Indonesia as a Global Maritime Fulcrum.

For the Minister of Foreign Affairs of the Republic of Indonesia, Retno Marsudi, GMF has become a new focus for Indonesia's foreign policy. For Retno, Indonesia's foreign policy still relies on the principle of being free and active, and Indonesia's diplomacy will highlight its character as a maritime country (Kemlu, 2015). Retno's statement seemed to emphasize that maritime diplomacy is the main instrument for her ministry to realize the idea of Indonesia's maritime axis. Even the ministry of foreign affairs has included a maritime vision in the 2015-2019 Ministry of Foreign Affairs Strategic Plan. The strategic plan has the slogan "Diplomacy for the people" and the vision "The realization of the authority of diplomacy to strengthen national identity as a maritime country for the benefit of the people". Briefly, the 2015-2019 Ministry of Foreign Affairs Strategic Plan outlines three missions, three objectives, and eight strategic targets. The three missions of the Ministry of Foreign Affairs are, first, to strengthen Indonesia's leadership as a maritime country on the international stage. Second, Indonesian Representatives with quality and integrity. Third, strengthen the Ministry of Foreign Affairs as the executor of foreign relations under the Nawa Cita National Medium-Term Development Plan and the Ministry's Strategic Plan (Fitriani \& Panduwinata, 2018).

This critical affirmation of the GMF vision is inseparable from Jokowi's vision and mission during the 2014 presidential election. Jokowi explained that the development of Indonesia's maritime areas is intrinsically related to the country's material progress in terms of increasing trade, inter-island connectivity, and securing maritime resources. It is also a unifying way for investment and development to support the more abstract idea of Indonesia as an archipelagic nation. Jokowi projects the concept as a theme in bilateral cooperation with foreign partners (Sambhi, 2015).

However, in reality, GMF did not meet the target. Jokowi no longer mentions GMF in his presidential inauguration speech before the People's Consultative Assembly in 2019 as when he was sworn in in 2014. The discontinuation of the program raises questions regarding the sustainability of the program. Jokowi once admitted that the GMF program did not work well in Indonesia because many other countries had the same problems as Indonesia (Maharani, 2016). Susan Herawati, SecretaryGeneral of the People's Coalition for Fisheries Justice, assessed that the GMF program had failed to be implemented (CNN Indonesia, 2019). According to Bambang Haryo Soekartono as an 
observer and expert on logistics transportation, this failure was due to the inability of Jokowi's ministers to translate the meaning of the maritime axis (Fanani, 2019).

This article attempts to explain the factors causing the failure of Indonesia's GMF vision through two approaches, namely individual variables (Leadership) and government variables (governmental). The individual variable will focus on the leading factor of a Jokowi, while the government variable will focus on government elites such as bureaucrats and ministers. It will be further explained as follows:

\section{Individual Approach (Leadership)}

According to James Rosenau, this individual variable has a vital role in the success or failure of a foreign policy. Rosenau explained that individuals could recognize and articulate interests. Even with existing authority, individuals have a greater capacity to know when, where, and how to engage in collective policies (Rosenau, 2006). Then it was emphasized again by Andrea Grove (2007), who said that psychologically the behaviour of the state in the context of international politics could be explained by various individual characteristics. Such as the personality and motivation of the leader, the way to understand the situation at hand, the advisory work system, to the way a leader reacts to domestic political pressure. Grove also divides this type of leadership into four main categories: first, "great man", a leader seen from his character, charisma, background, and political experience. Second, "firefighters", leaders who lack originality and freedom of action. The born policy was only a reaction to the events that occurred (current situation). Third, "the puppet", a leader who is influenced by his followers, advisors, and political partners. The character of the followers is an essential factor to measure this type of leader. Fourth, "salesmen", leaders who are sensitive to what the public wants and try to realize the public interest (Grove, 2007) (Grove, 2007). With these four types, it can then be described the role of a leader in various policies related to the international political context.

Based on these theoretical arguments, this article describes the role of Jokowi's leadership in implementing his foreign policy related to the maritime axis. The various components of leadership described by Rosenau, and Grove will be the basis for looking at the failure factors of the world maritime axis from Jokowi's leadership approach. Be it personality background, political experience, advisors, and supporters, to policy implementation in the context of international policy. Grove's categorization of leaders is also an assessment of Jokowi's lead character. It is hoped that this type of leadership character can be a firm answer to the lack of implementation of the idea of Indonesia as a maritime axis. 
This governmental approach aims to explain the critical role of policy-making elites, including bureaucrats, in the succession of a country's foreign policy. In Rosenau's view, the bureaucratic elite takes the role of a follower rather than a leader (Rosenau, 2006). Even though elite bureaucrats exert influence in foreign policy, they cannot be separated from the orders of the head of state. Scientifically, Linda P. Brady and Charles W. Kegley (1977) examined the strategic role of these bureaucrats in foreign policy. Brady and Kegley are based on the view of Charles Hermann. He assumes that the bureaucratic paradigm focuses on the structure and processes of decisionmaking and implementation used by government units. In the findings of Brady and Kegley, countries that actively participate in the international arena tend to legitimize foreign policy decisions by individuals who are the highest echelons of the government structure. In addition, bureaucratic participation and the degree of institutionalization are positively correlated with the amount of conflict behaviour initiated by the state (Brady \& Charles W. Kegley, 1977).

In Jokowi's administration, the government unit coordinating the GMF idea is the Coordinating Ministry for Maritime Affairs. These maritime tasks were then delegated to subordinate government units such as the ministry of maritime affairs, ministry of transportation, ministry of foreign affairs and several other ministries. Each ministry has its primary duties and responsibilities according to the organizational framework of its institution. The relationship between ministry agencies and the various policies presented are significant determinants of the structure and process of forming the idea of Indonesia as the world's maritime axis. Even Brady and Kegley are also considering the relationship of the head of state, in this case, Jokowi, with his ministers regarding Indonesia's foreign policy output.

Both approaches are fundamental, considering that the idea of the maritime axis was spoken directly by Jokowi as an individual actor. Policy implementation was carried out at the governmental level. Jokowi's instructions to his ministers illustrate the relationship between the individual and the government. Jokowi places the world maritime axis on his priority agenda in his "Nawa Cita" (Kompas.com, 2014). Starting from Nawa Cita, Jokowi's ministers formulated various government policies related to forming the idea of the world maritime axis. Therefore, the author considers the importance of looking at the failure factors of Indonesia's maritime diplomacy as a pillar of the formation of the world maritime axis from these two approaches.

Studies related to Indonesia as the global maritime fulcrum have become the research studies of several scholars from various disciplines. Among them are from political science, public policy to international relations. Several previous studies that analyzed GMF consisted of 3 significant studies, namely security studies (Agastia \& Perwita, 2018; Al Syahrin, 2018; Hudaya \& 
Putra, 2017; Nugraha \& Sudirman, 2016), international cooperation (Nainggolan, 2016; Pradhan, 2016; Quirk \& Bradford, 2015; Sriyanto, 2018), regional and geopolitics (Ali \& Sulistiyono, 2020; Andika, 2017; Aufiya, 2017; Yani \& Montratama, 2018).

First, the security study explains that the vision of the GMF is Indonesia's ambitious program to secure its sovereign territory from potential threats. In dealing with potential threats, an important instrument that must be considered is the capability of maritime diplomacy and increasing the capabilities and weapon systems of the Indonesian National Army (TNI), especially the Navy (Nugraha \& Sudirman, 2016). Various potential threats in Indonesia's marine areas can be minimized. Both traditional and non-traditional security threats. This security threat was identified by Al Syahrin (2018) in his article, which states that piracy, terrorism, illegal logging and illegal immigrants are the dominant types of non-traditional threats. The increasing number of international ships passing through Indonesian waters allows the occurrence of maritime piracy crimes. This phenomenon is assessed as a form of vulnerability from the security aspect, but the economic loss is tremendous (Al Syahrin, 2018). According to Hudaya \& Putra (2017), one of the reasons this threat is still ongoing is the error of several doctrines that have developed at the community level to the level of policymakers, including the doctrine of national defence. Especially the strong culture of piracy in Indonesian coastal communities. Through the Sea Power theory from Alfred Thayer Mahan, Hudaya \& Putra (2017) argue that resolving maritime security gaps in Indonesia must be done by accumulating maritime power in quality and quantity. Ultimately, to achieve the ambitions of the World Maritime Axis, Indonesia needs to seriously consider the physical aspects of maritime development and develop maritime awareness and doctrine for its regional ambitions (Agastia \& Perwita, 2018). The way to do this is to rely on its capabilities and engage its regional neighbours through cooperation. It will be explained in the second study.

The second study examines that the vision of GMF Indonesia can be an instrument for Indonesia to strengthen international cooperation in the maritime sector. For example, Nanto Sriyanto, in his article, stated that the GMF program opened up cooperation opportunities for China to invest and build complementary cooperation with China's Belt Road Initiatives (BRI). Nevertheless, Indonesia's position as a middle-power must also consider cooperation with other countries, especially those in line with strengthening ASEAN's centrality to protect the principle of dynamic balance and its role as a bridge between the great powers (Sriyanto, 2018). Moreover, China's strength as a great power will be rugged for Indonesia to match. It is proven by the several penetrations of Chinese fishing vessels in Indonesia's sovereign territory, in North Natuna. China claims the territory is its sovereignty. Therefore, according to Sanjeevan Pradhan, the two sides 
still need to fix certain aspects of the military and government functions so that cooperation can run smoothly. Indonesia needs to reduce the bureaucracy that currently hinders foreign investment.

In contrast, China needs to reduce its growing assertiveness in the South China Sea to convince Indonesia of its intention to forge genuine cooperation (Pradhan, 2016). Another balance that Indonesia can do is establish cooperation with the United States, which also has military power in the Pacific. Cooperation can be done with more sophisticated and complex joint training between the US and Indonesian forces. The focus should be on developing the capabilities Indonesia needs to defend its sovereign maritime space from traditional and non-traditional threats without compromising Indonesia's non-aligned policies (Quirk \& Bradford, 2015). Indonesia must also involve its regional partners, namely ASEAN member countries. It is expressed by Nainggolan (2015) in his article. There has been a positive response from several countries such as Vietnam and the Philippines that support Indonesia's PMD policy. Thailand and Malaysia, which were initially critical of Indonesia's firm policy regarding the sinking of illegal fishing vessels, are finally willing to cooperate with Indonesia regarding the security of marine areas (Nainggolan, 2016). In this study, Sriyanto (2018) and Nainggolan (2016) emphasize that the central role of ASEAN is significant to support Indonesia's GMF vision. Regional-based cooperation has domestic implications for Indonesia and influences geopolitical changes, focusing on the analysis of the third study.

Furthermore, the third study analyzes the broader vision of GMF Indonesia, namely a regional review and also geopolitical implications. For example, Yani and Montratama's (2018) article found that GMF Indonesia's vision is Indonesia's bargaining tool to fight for influence in the Indo-Pacific region. Previously, Japan and India had already launched the Confluence of the Two Seas concept in 2007, followed by the United States with Rebalancing toward Asia in 2011, and China with the 21st Century Maritime Silk Road in 2013 (Yani \& Montratama, 2018). Not only that but Indonesia's maritime awareness was also triggered by historical experiences, namely the glory of Sriwijaya and Majapahit as maritime powers that were feared in the region. Therefore, the efforts of the Joko Widodo government to popularly echo the GMF not only for domestic needs but also for stability and struggle for influence in the region (Aufiya, 2017). To maintain regional stability, one of Indonesia's efforts is its seriousness in regulating maritime border areas. In Ali and Sulistiyono (2020) findings, the GMF doctrine has encouraged the Indonesian government's efforts to take serious action on maritime border diplomacy. It can be seen from several pieces of evidence. Such as negotiations on the opening of maritime boundaries with Timor Leste, negotiations on exclusive economic zone (EEZ) boundaries with Vietnam and Malaysia, continuing negotiations on the boundaries of the continental shelf with the Philippines, and the ratification of a 
maritime agreement with Singapore, which has entered the final stage. It can be said that in this third study, GMF Indonesia's vision also influences the geopolitical order in the Indo-Pacific region in order to maintain regional stability.

Departing from these three studies, there are no articles that examine the vision of GMF Indonesia as a critical policy review. Nevertheless, the author appreciates that many cross-scientific academics have conducted research related to GMF. Many academics who discuss GMF see that this ambitious vision can strengthen Indonesia's bargaining position in the region. It is just that the discussion space is dominated by the scope of international studies, whether it is talking about international cooperation, geopolitics, security and regional stability. No one has researched GMF as a national policy in the domestic scope through a critical policy review. Therefore, the author tries to fill the space of this research through research questions, why the vision of GMF Indonesia cannot be adequately implemented? Analytically, the author analyzes based on leadership and governmental factors.

Based on these arguments, through this article, the author aims to analyze further the causes of Indonesia's failure as the world's maritime axis. Jokowi and his working cabinet are the objects of significant research in this regard. This article argues that the cause of implementing GMF that is not optimal is due to inter-ministerial disputes and Jokowi's lack of leadership related to the world maritime axis policy, which serves as a guide for his ministers. With the existing methodological and analytical tools, the author will describe the causal relationship between the strategic role of the president and his ministers with the implementation of the maritime axis policy.

\section{METHODS}

Methodologically, this article is qualitative research with a Causal Process Tracing (CPT) mechanism to find research answers. CPT in the social sciences seeks to explain the causal mechanism that takes place in an event. The CPT method offers significant potential for answering some of the critical research questions related to policy studies. The single advantage of CPT for policy studies is manifested in a more robust method of understanding the causality of policy change events while enabling comparisons between single case studies (Kay \& Baker, 2015). In this context, the intended case study is the reason behind the lack of success of GMF Indonesia during Jokowi's first term of leadership.

The type of data obtained is secondary data with archival data collection methods and document-based research. The author conducts literature studies and searches for news, especially from online media and official government websites. The writer then tested the relevance 
of the data obtained with the research needs through triangulation of data sources. This triangulation process is used to confirm one data source with other data sources so that the strength of its validity and reliability is tested. Furthermore, the author will take a narrative approach in constructing the findings to become a liaison for the analysis of the research problem formulation.

\section{RESULTS AND DISCUSSION}

The GMF, one of President Joko Widodo's mainstay policies in his first term of leadership, has not yet been appropriately implemented. Problems within the Indonesian government itself also cause the failure to implement President Jokowi's great ideals. There are at least two problems, namely bureaucratic problems and coordination problems. Bureaucratic problems stem from the absence of an integrated legal umbrella related to the pillars of the world maritime axis and the absence of a master plan for implementing the world maritime axis. This problem is then closely related to other problems, namely poor coordination between related agencies.

\section{Bureaucratic Problems}

At this time, there are too many rules or legislation governing matters relating to GMF. The absence of integrated laws and regulations regarding matters related to the GMF policy then impacts two things. First, the authority is spread over various ministries and institutions. These agencies include the Ministry of Maritime Affairs and Fisheries, the Ministry of Transportation, the Ministry of the Environment, the Water and Air Police, to the Indonesian Navy. Even in 2014, Jokowi established the Maritime Security Agency through Presidential Decree No. 178 of 2014 (Sekretariat Kabinet, 2014). Second, the overlapping authority of these agencies is detrimental to the related parties. The overlapping authority between these agencies can be seen in several aspects. The first aspect is law enforcement and security at sea. In this aspect, overlapping authority occurs between the Water and Air Police, the Navy and the Marine Security Agency as well as the Maritime and Coast Guard Unit of the Ministry of Transportation, the Marine and Fishery Resources Supervision Officer of the Ministry of Maritime Affairs and Fisheries (CNN Indonesia, 2015; Sari, 2019). This overlap in maritime security aspects alone has created a contradictory impact with GMF policies. As is known, GMF was created to bring in world cargo ships through Indonesian territory. However, with this problem of overlapping authorities, domestic shipping entrepreneurs have already voiced their disadvantages (Sari, 2019).

In addition to the maritime security aspect, the overlapping authority that thwarts the implementation of GMF also occurs in the licensing aspect. The permits in question are export permits and ship permits to go to sea (Hamdani, 2019). Licensing for entrepreneurs engaged in 
marine and fisheries is currently in different ministries and institutions. In addition, this condition is exacerbated by the complexity of the bureaucracy that must also be faced. These things are detrimental for fishers and entrepreneurs engaged in the marine and fisheries sector because it increases operational costs and makes it difficult for export space (Merdeka.com, 2019; Sari, 2019).

For example, capture fisheries entrepreneurs must obtain permits from two different ministries, namely the Ministry of Maritime Affairs and Fisheries and the Ministry of Transportation. The Ministry of Maritime Affairs and Fisheries refers to Law no. 45 concerning fisheries is only authorized to issue Fishery Business Permits, Fishing Permits and Fish Transport Vessel Permits (Hamdani, 2019). Meanwhile, the ship's operational permit must go through the Ministry of Transportation (Hamdani, 2019). During the permit processing process and the validity period of all these permits, the bureaucratic stages vary, so cases are often found where a recently operated ship must stop because one of the permits has expired (Garnesia, 2018; Hamdani, 2019).

In addition, entrepreneurs who are engaged in ornamental fish cultivation are also affected by the complexity of the licensing process (Merdeka.com, 2019). Entrepreneurs engaged in ornamental fish farming, for example, stated that Indonesia's export volume was still low due to the complexity of the licensing process and the costs involved. The export volume of Indonesian ornamental fish is even far behind that of Singapore. This condition is ironic considering that Indonesia's ocean area far exceeds that of Singapore and has been known to have various types of ornamental fish. The complexity of the bureaucracy in obtaining this permit has been confirmed directly by the assistant deputy for biological resources at the Coordinating Ministry for Maritime Affairs and Investment (Merdeka.com, 2019).

Bureaucratic problems that thwarted Jokowi's GMF policy were exacerbated by the absence of a program implementation master plan. The absence of a master plan or national strategy in implementing the world maritime axis is known from the statement of the Minister of Maritime Affairs and Fisheries of Indonesia for the period 2014-2019 Susi Pudjiastusti. Susi even stated that the existing RPJMN is a legacy from the past government (Kompas.com, 2017). In addition, the absence of a GMF implementation master plan was also confirmed by a reviewer from the National Resilience Institution (LEMHANAS) Rear Admiral TNI Untung Suropati (Kompas.com, 2016). The absence of this master plan causes agencies that have the authority related to implementing the GMF to have different interpretations. These different interpretations then lead to different implementation strategies in each ministry and institution.

Troubled Inter-Ministerial Coordination. 
In addition to the bureaucratic factors mentioned above, problems also arise from the poor coordination between ministries. This section argues that problematic inter-ministerial coordination causes GMF not to be implemented properly, especially between the Minister of Maritime Affairs and Fisheries Susi Pujiastuti and other ministers. Initially, Susi issued a moratorium on ship licensing, which was agreed and signed by the Minister of Law and Human Rights, Yasonna Laoly. However, Yasonna disagreed with Susi about the ship's sinking because it did not have suitable regulations (Tempo.co, 2014). The disagreement between the two ministers regarding implementation shows that the GMF concept is not ready to reach the implementation stage because of different perceptions of what can and cannot be done.

The discrepancy described above is at the ministerial level and the president-vice president levels, although the centre of the tension remains with Susi. In her first month in office, Susi received Jokowi's support to "sink a hundred ships" to message that Indonesia is serious about maintaining its maritime sovereignty (Tempo, 2014). However, Vice President Jusuf Kalla instead asked Susi to stop the sinking of foreign fishing vessels suspected of stealing in the Indonesian sea (Kompas.com, 2018). Furthermore, Jusuf Kalla said that the request to stop the drowning was a 'government view', implying that Susi was an entity outside the government. The neglect of Susi in the cabinet is a form of inter-ministerial miscoordination that is not mediated through clear leadership, in this case, the leadership of Vice President Jusuf Kalla.

Susi also has a fundamental difference with Luhut B. Pandjaitan as Coordinating Minister for Maritime Affairs. In 2018, Luhut asked Susi not to sink any more boats because the vessels confiscated by the state could be given to fishing cooperatives, but Susi said that sinking vessel is a law mandate (Andreas, 2018). In addition, Luhut and Susi also questioned other matters related to fisheries practices in the cabinet, such as "cantrang". The culmination of the dispute between the two ministers occurred when Luhut explained a plan to open the faucet for foreign investment in Natuna waters in the field of capture waters, where Susi said she was ready to resign if this happened. Jusuf Kalla said that he supported Luhut's plan (Andreas, 2018). This presentation illustrates a mismatch between the Minister of Maritime Affairs and Fisheries and the Coordinating Minister for Maritime Affairs, confusing the implementation of GMF.

\section{Leadership Factor}

This paper looks at Jokowi's lack of participation as a top leader. The description above shows how Susi, Luhut, and Vice President Jusuf Kalla played the roles, but Jokowi does not seem to manage this dispute well. It shows that Jokowi does not show political leadership in interministerial miscoordination. Political leadership is essential to break deadlocks and penetrate 
political boundaries due to political phenomena, such as the GMF case (Peral, 1997). Thus, this section sees that the sectoral ego and miscoordination that occurred in the ship sinking policy was exacerbated by the weak political leadership shown by Jokowi.

The weakness of political leadership in Jokowi's leadership was also seen at the beginning of his leadership. The cabinet announcement, initially scheduled for October 20 2014, was pushed back to November 24 due to the many interests of the supporting parties. It is a sign that the people around him still influence Jokowi. Then when the cabinet ministers and transition teams announced, many strategic positions were not filled by qualified and trusted people but were filled by people close to Megawati (the leader of the PDI-P) or Surya Paloh (the leader of NASDEM) (Fukuoka \& Djani, 2016). Such as the appointment of Rini Soewandi (PDI-P) as Minister of State-Owned Enterprises. The Corruption Eradication Commission has marked Rini Soewandi as a person who is prone to be involved in corruption cases. However, Jokowi still chose him because of Rini Soewandi's close relationship with Megawati. Megawati forced Jokowi to include Rini in the cabinet and Puan Maharani (PDI-P) as the Coordinating Minister for Human Resource Development and Culture. This appointment is quite controversial because Puan Maharani has no experience in government agencies. However, Puan was still appointed as Minister because of her position as Megawati's daughter. Next was the election of PDI-P deputy secretary-general Hasto Kristiyanto, Andi Widjajanto and NASDEM party politician Akbar Faisal as members of the transition team (Fukuoka \& Djani, 2016).

Another problem is also seen in the budgeting process and setting up the work tasks carried out by Jokowi. Referring to the National Medium-Term Development Plan (RPJMN) 2015-2019, several ideas and steps have been mentioned to enforce the implementation of the maritime axis vision, such as the establishment of the Maritime Security Agency (BAKAMLA). This institution is given the task of conducting security and safety patrols in Indonesia's marine area and jurisdiction, which will also be the guardian of the world's maritime axis (Ramadhani \& Aliabbas, 2015). Instead of forming a new agency like Bakamla, Jokowi should optimize the Navy to become a respected maritime force in the Indo-Pacific region. The Jokowi administration must also prioritize maritime power development in the second phase of the Minimum Essential Force (MEF) from 2015 to 2019. Military observer lis Gindarsah noted that the existing MEF plan does not appear adequate to address the emerging challenges (Gindarsah \& Priamarizki, 2015).

In 2014, the Ministry of Defense published several defence policy papers: Defense White Paper, National Defense Doctrine, State Defense Strategy, State Defense Posture and minimum essential troop harmonization 2014 (Ramadhani \& Aliabbas, 2015). However, GMF's vision is not 
reflected in these defence policy products. Not only that, the two documents do not specify the maritime axis vision as a focal perspective. In other words, this gap shows the incoherence between Jokowi's vision and the development of the defence sector.

Since the beginning of his leadership, Jokowi was not interested in foreign policy issues. Jokowi focuses on strengthening domestic politics in contrast with President Susilo Bambang Yudhoyono (SBY), who tends to be outward-looking. SBY often appears in critical international forums while offering Indonesia's economic interests. In 2016, for the second year in a row, Jokowi missed the opportunity to deliver a speech at the opening of the annual session of the United Nations General Assembly. In addition, for the second year in a row, Jokowi has not attended the Asia-Pacific Economic Cooperation (APEC) leaders' meeting. The forum presented Barack Obama (United States), Xi Jinping (China), and Vladimir Putin (Russia) attended by twenty-one countries (Weatherbee, 2017). These meetings are an essential forum to offer the vision of GMF to Asia Pacific countries internationally.

Another more contrasting thing is Jokowi's attitude that he relies on Luhut for foreign affairs, which incidentally is not the Minister of Foreign Affairs. At that time, Luhut's position was still as Chief of Staff to the President, then became Coordinating Minister for Political, Legal and Security Affairs. The latter supervised the Ministry of Foreign Affairs in his direction. Later he became Coordinating Minister for Maritime Affairs. Luhut almost always stands out in his dealings with China (Weatherbee, 2017). This condition is contrary to Indonesian foreign policy tradition, which the Ministry of Foreign Affairs usually handles.

In addition, Luhut is also an intellectual actor who initiated the vision of GMF Indonesia with Rizal Sukma. Conceptually, Rizal Sukma explained that GMF is Indonesia's effort to maintain harmonization of relations with China and the United States in the region without having to sacrifice its relationship with one of them. Sukma also described Jokowi's foreign policy to maintain equal relations with China and the United States. At the same time, this GMF vision is the reason for forming the Coordinating Ministry for Maritime Affairs (Weatherbee, 2017). It seems clear that although Jokowi echoes GMF as his ultimate vision, the originality of the idea is not from him. As a result, the level of implementation of the vision does not go well. Even Aaron Connely, an observer of the foreign policy, argue that Jokowi's conceptualization of Indonesia as the global maritime fulcrum is not about maritime projections but instead on a domestic-focused vision (Connelly, 2015).

This article shows how an established public policy must be prepared by involving many parties, namely the government (inter-ministerial institutions), intellectuals, activists and civil 
society. That way, clear and measurable guidelines or blueprints can be created to be implemented by various related parties. GMF is an ambitious vision that must be continuously implemented. This research seeks to identify problems and challenges to contribute to the improvement of the program in the future, including the next Indonesian leader who wants to continue this GMF vision. This study highlights GMF at the level of policymakers. Miscoordination and conflict between elites and the lack of intervention by leaders make this excellent public policy only a symbol of valour. Allan McConnell and Paul Hart (2019) refer to this situation as policy inaction, namely as an instance and/or pattern of non-intervention by individual policymakers, public organizations, governments or policy networks in relation to an issue within and potentially within their jurisdiction and where other plausible potential interventions policy did not take place.

This article is only limited to challenges and problems at the elite government level; future research opportunities can find out the successes and failures of GMF from an economic point of view. An economic perspective can identify how effective the development of maritime infrastructure is to support the realization of the GMF vision. In recent years, Indonesia has been speeding up its infrastructure projects (such as seaports) to accelerate economic growth by connecting provinces in Indonesia.

\section{CONCLUSIONS}

Jokowi's vision that prioritizes maritime aspects through GMF must be appreciated. The idea of GMF builds awareness of the Indonesian people about the character of a great maritime nation. This maritime vision has become the hallmark of Joko Widodo in his free-active foreign policy. Jokowi hopes to marry a maritime vision, and a free-active foreign policy did not turn out well. If this goes well, Jokowi has a free and active character that is different from previous presidents. However, in his first term, Jokowi did not maximize his leadership abilities. As a result, these ideas are mere rhetoric.

Therefore, it can conclude that the failure to implement the global maritime fulcrum occurs due to two factors: governmental and individual factors. This failure occurred because the ministers in the Working Cabinet did not have similarities in translating the concept of the world maritime axis. The absence of a significant blueprint makes this vision unable to be manifested in the ministry's work program. As a result, there is no clear work map, miscoordination between ministers, and even conflicts between ministries and other state institutions. It is exacerbated by the lack of Jokowi's leadership, which does not provide clarity as a top leader related to the maritime axis concept in a single definition. Hopefully, there is no more protracted debate within the ranks of 
ministers. The two factors are intertwined, but the critical factor that causes this problem to persist is Jokowi's minimal intervention in inter-ministerial disputes. As a president, Jokowi did not prepare a blueprint or any specific guidelines for the succession of GMF's vision in his first term. In the end, GMF just became Jokowi's populist policy.

This study recommends that the government make a policy blueprint with a clear command line and division of tasks, from the president to the relevant ministries or institutions. That way, the division of tasks between institutions becomes apparent, and the implementation does not overlap. In addition, the government must provide a legal basis for the realization of each Minister's program.

\section{REFERENCES}

Agastia, I. G. B. D., \& Perwita, A. A. B. (2018). Building Maritime Domain Awareness as an Essential Element of the Global Maritime Fulcrum: Challenges and Prospects for Indonesia's Maritime Security. Jurnal Hubungan Internasional, 6(1), 260764.

Al Syahrin, M. N. (2018). Kebijakan Poros Maritim Jokowi dan Sinergitas Strategi Ekonomi dan Keamanan Laut Indonesia. Indonesian Perspective, 3(1), 1-17. https://doi.org/10.14710/ip.v3i1.20175

Ali, I., \& Sulistiyono, S. T. (2020). A Reflection of "Indonesian Maritime Fulcrum" Initiative: Maritime History and Geopolitical Changes. Journal of Maritime Studies and National Integration, 4(1), 12-23. https://doi.org/10.14710/jmsni.v4i1.8081

Andika, M. T. (2017). Indonesia Border Diplomacy Under The Global Maritime Fulcrum. Ritsumeikan International Affairs, 15(September), 45-66.

Andreas, D. (2018). Luhut vs Susi: Dari Cantrang Hingga Penenggelaman Kapal. Tirto.Id. https://tirto.id//uhut-vs-susi-dari-cantrang-hingga-penenggelaman-kapal-cC3H

Aufiya, M. A. (2017). Indonesia's Global Maritime Fulcrum: Contribution in the Indo-Pacific Region. Andalas Journal of International Studies, 6(2), 143-159.

Brady, L. P., \& Charles W. Kegley, J. (1977). Bureaucratic Determinants of Foreign Policy: Some Empirical Evidence. International Interactions, 3(1), 33-50.

CNN Indonesia. (2015). Tumpang-tindih Aturan Penegakan Hukum Maritim. https:/www.cnnindonesia.com/nasional/20151004163018-20-82691/tumpang-tindih-aturanpenegakan-hukum-maritim

CNN Indonesia. (2019). Habibie Center: Jokowi Kecewa Anak Buah Tak Paham Maritim. CNN Indonesia. https://www.cnnindonesia.com/nasional/20190806135604-20-418864/habibiecenter-jokowi-kecewa-anak-buah-tak-paham-maritim 
Connelly, A. L. (2015). Sovereignty and the sea: President Joko Widodo's foreign policy challenges. Contemporary Southeast Asia, 37(1), 1-28. https://doi.org/10.1355/cs37-1a

Fanani, A. (2019). Indonesia Kehilangan Potensi Poros Maritim Dunia karena Kebijakan Ini. Detik.Com. https://news.detik.com/berita-jawa-timur/d-4786086/indonesia-kehilanganpotensi-poros-maritim-dunia-karena-kebijakan-ini

Fitriani, \& Panduwinata, V. C. (2018). Analisis Kinerja Kementerian Luar Negeri Indonesia (20152018).

Fukuoka, Y., \& Djani, L. (2016). Revisiting the rise of Jokowi: The triumph of reformasi or an oligarchic adaptation of postclientelist initiatives? South East Asia Research, 24(2), 204-211. https://doi.org/10.1177/0967828X16649044

Garnesia, I. (2018). No Perikanan Tangkap: Masalah Perizinan Tetap Ada. Tirto.ld. https://tirto.id/perikanan-tangkap-masalah-perizinan-tetap-ada-c8oN

Gindarsah, I., \& Priamarizki, A. (2015). Indonesia's maritime doctrine and security concerns.

Grove, A. K. (2007). Political Leadership in Foreign Policy: Manipulating Support across Borders. Palgrave Macmillan.

Hamdani, T. (2019). Dipermudah, Urus Izin Kapal Ikan Nanti Hanya ke KKP. Detik.Com. https://finance.detik.com/berita-ekonomi-bisnis/d-4809653/dipermudah-urus-izin-kapal-ikannanti-hanya-ke-kkp

Hudaya, M., \& Putra, A. T. (2017). Toward Indonesia as Global Maritime Fulcrum: Correcting Doctrine and Combating Non-Traditional Maritime Threats. Jurnal Hubungan Internasional, 10(2), 72-85.

Indonesia.go.id. (2019). Indonesia Poros Maritim Dunia. https://indonesia.go.id/narasi/indonesiadalam-angka/ekonomi/indonesia-poros-maritim-dunia

Kay, A., \& Baker, P. (2015). What can causal process tracing offer to policy studies? A review of the literature. Policy Studies Journal, 43(1), 1-21. https://doi.org/10.1111/psj.12092

Kemlu. (2015). Pernyataan Pers Tahunan Menlu RI: Diplomasi Indonesia akan Menonjolkan Karakter sebagai Negara Maritim. Tabloid Diplomasi.

Kompas.com. (2014). "Nawa Cita", 9 Agenda Prioritas Jokowi-JK. Kompas. https://nasional.kompas.com/read/2014/05/21/0754454/.Nawa.Cita.9.Agenda.Prioritas.Joko wi-JK

Kompas.com. (2016). Poros Maritim Tanpa Strategi. Kompas. https://nasional.kompas.com/read/2016/09/01/21352891/poros.maritim.tanpa.strategi Kompas.com. (2017). Susi Pudjiastuti: Indonesia Poros Maritim Dunia Hanya Slogan Doang? 
Kompas. $\quad$ https://nasional.kompas.com/read/2017/10/30/09370631/susi-pudjiastutiindonesia-poros-maritim-dunia-hanya-slogan-doang

Kompas.com. (2018). Wapres Minta Menteri Susi Hentikan Penenggelaman Kapal. Kompas. https://nasional.kompas.com/read/2018/01/09/17501971/wapres-minta-menteri-susihentikan-penenggelaman-kapal?page=all

Maharani, E. (2016). Jokowi Akui Poros Maritim Dunia Banyak yang Belum Berjalan. Republika. https://www.republika.co.id/berita/oc7nqs335/jokowi-akui-poros-maritim-dunia-banyak-yangbelum-berjalan

McConnell, A., \& 't Hart, P. (2019). Inaction and public policy: understanding why policymakers 'do nothing.' Policy Sciences, 52(4), 645-661. https://doi.org/10.1007/s11077-019-09362-2

Merdeka.com. (2019). Pemerintah akan Pangkas Perizinan Ekspor Ikan Hias. https://www.merdeka.com/uang/pemerintah-akan-pangkas-perizinan-ekspor-ikan-hias.html Nainggolan, P. P. (2016). Kebijakan poros maritim dunia Joko Widodo dan implikasi internasionalnya. Politica, 6(2), 167-190.

Nugraha, M. H. R., \& Sudirman, A. (2016). Maritime Diplomacy Sebagai Strategi Pembangunan Keamanan Maritim Indonesia. Jurnal Wacana Politik, 1(2), 175-182. https://doi.org/10.24198/jwp.v1i2.11059

Peral, A. N. (1997). Political leadership: A tentative framework. Journal of Leadership and Organizational Studies, 4(3), 68-83. https://doi.org/10.1177/107179199800400307

Pradhan, S. (2016). Contradictions, China's Maritime Silk Route and Indonesia's Global Maritime Fulcrum: Complements and. ICS Occasional Paper, 12, 1-18.

Quirk, B. S., \& Bradford, J. (2015). Maritime Fulcrum : A New U.S. Opportunity to Engage Indonesia (Vol. 15, Issue 9).

Ramadhani, M. A., \& Aliabbas, A. (2015). Some remaining problems facing Jokowi's maritime axis vision. Jakarta Post. https://www.thejakartapost.com/news/2015/12/21/some-remainingproblems-facing-jokowi-s-maritime-axis-vision.html

Rosenau, J. N. (2006). The Study of World Politics, Volume 2: Globalization and Governance. (Routledge).

Sambhi, N. (2015). Jokowi's 'Global Maritime Axis' Smooth Sailing or Rocky Seas Ahead? Security Challenges, 11(2), 39-55. https://www.jstor.org/stable/26465437

Sari, S. M. (2019). Pelayaran Klaim Merugi Akibat Tumpang-tindih Hukum di Laut. Bisnis.Com. https://ekonomi.bisnis.com/read/20190513/98/921770/pelayaran-klaim-merugi-akibattumpang-tindih-hukum-di-laut 
Sekretariat Kabinet. (2014). Inilah Perpres No. 178/2014 Tentang Pembentukan Badan Keamanan Laut. $\quad$ https://setkab.go.id/inilah-pepres-no-1782014-tentang-pembentukan-badankeamanan-laut/

Sriyanto, N. (2018). Global Maritime Fulcrum, Indonesia-China Growing Relations, and Indonesia'S Middlepowermanship in the East Asia Region. Jurnal Kajian Wilayah, 9(1), 1-19. https://doi.org/10.14203/jkw.v9i1.784

Tempo.co. (2014). Kementerian Keuangan Bebaskan Pajak Impor Oksigen untuk Penanganan Covid-19. Tempo. https://bisnis.tempo.co/read/1480378/kementerian-keuangan-bebaskanpajak-impor-oksigen-untuk-penanganan-covid-19

Weatherbee, D. E. (2017). Indonesia's Foreign Policy in 2016: Garuda Hovering. Southeast Asian Affairs, 163-176.

Yani, Y. M., \& Montratama, I. (2018). Indonesia Sebagai Poros Maritim Dunia: Suatu Tinjauan Geopolitik. Jurnal Pertahanan \& Bela Negara, 5(2), 25-52. https://doi.org/10.33172/jpbh.v5i2.356 